\title{
Oxygen and nitrogen isotopes as tracers of fluid activities in serpentinites and metasediments during subduction
}

\author{
Pascal Philippot $^{1}$, Vincent Busigny ${ }^{2,4}$, Marco Scambelluri ${ }^{3}$ and Pierre Cartigny ${ }^{4}$
}

${ }^{1}$ Laboratoire Géobiosphère Actuelle et Primitive, Institut de Physique du Globe de Paris, CNRS UMR 7154, 4 place Jussieu, 75252 Paris Cedex 05, France

${ }^{2}$ Origins Laboratory - Department of the Geophysical Sciences, The University of Chicago, 5734 South Ellis Avenue Chicago, IL 60637, USA

${ }^{3}$ Dipartimento per lo studio del Territorio e delle sue Risorse, Università di Genova, Corso Europa 26, 16132 Genova, Italia

${ }^{4}$ Laboratoire de Physico-Chimie des Fluides Géologiques, Institut de Physique du Globe de Paris, CNRS UMR 7154, 4 place Jussieu, 75252 Paris Cedex 05, France

\begin{abstract}
$\mathrm{N}$ and $\mathrm{O}$ isotope systematics of a suite of high-pressure (HP) and ultrahigh-pressure (UHP) metasediments of the Schistes Lustrés nappe and metaperidotites of the Erro Tobbio Massif from the Alpine-Appennine system are compared with their unmetamorphosed or hydrothermallyequivalent from the same localities and from the South West Indian Ridge (SWIR). The HP and UHP rocks studied represent a sequence of pelagic sediments and altered ultramafic rocks subducted to different depths of down to $90 \mathrm{~km}$ along a cold geothermal gradient $\left(8^{\circ} \mathrm{C} / \mathrm{km}\right)$. Unmetamorphosed and HP metasediments show the same range in $\delta^{15} \mathrm{~N}$ values independently of their metamorphic grade and bulk nitrogen concentrations. Together with several other geochemical features $(\mathrm{K}, \mathrm{Rb}$ and $\mathrm{Cs}$ contents, $\delta \mathrm{D})$, this indicates that $\delta^{15} \mathrm{~N}$ values were unaffected by metamorphism and $\mathrm{N}$ was not released during subduction. $\mathrm{N}$ isotope analysis of serpentinites coupled with $\delta^{18} \mathrm{O}$ systematics envisages the involvement of a mafic (crustal) component during partial deserpentinization of the subducted oceanic mantle at the depth locus of island arc magmatism. This does not imply large-scale fluxes as the metagabbros are spatially associated with the analyzed serpentinites, rather preservation of presubduction chemical and isotopic heterogeneities on a local scale as documented for the metasediments.
\end{abstract}

\section{Introduction}

Fluids released during subduction of oceanic lithosphere recycle crustal component into the overlying mantle wedge and are ultimately involved in the production of arc magmas. They transfer 
a characteristic geochemical signature to arc volcanism that can be used to trace mass transfer through subduction processes. Most studies have concentrated on identifying the source of volatile elements in subducting slabs and evaluating the efficiency of volatile recycling in subduction through the use of isotope and gas chemistry of island arc magmas (Fischer et al., 2002; Zimmer et al., 2004). Data on stable $\mathrm{N}$ and $\mathrm{C}$ isotopes suggest that most of the carbon is transferred to the mantle (Shaw et al., 2003; Synder et al., 2001), whereas $\mathrm{N}$ is largely returned back to the surface via volcanic degassing (Fischer et al., 2002). Another way to document more directly the source and behavior of volatiles in subduction zones is to study oceanic material that has been subducted to different depths. Metasediments and serpentinites are the two main carriers of volatiles at convergent margins. Although the understanding of high-pressures phase relations in pelitic systems and hydrous ultramafites has considerably been improved (Poli and Schmidt, 2002; Pawley and Holloway, 1993; Ulmer and Trommsdorff, 1999; Hermann and Green, 2001), knowledge about their volatile and mobile element fingerprints (e.g. B, Li, Cl, N) at high and ultrahigh pressures is still incomplete. An inventory of such tracers is available for mafic rocks and metasediments subducted along warm geothermal gradients (Moran et al., 1992; Bebout and Fogel, 1992; Mingram and Braüer, 2001). Recently, Busigny et al., (2003a) showed that the contents of fluid-mobile elements like $\mathrm{N}, \mathrm{K}, \mathrm{Rb}$ and $\mathrm{Cs}$ of metasediments subducted in a cold slab environment remain unaffected by devolatilization and that $\mathrm{N}$ is effectively transported down to at least $100 \mathrm{~km}$ depths. This is in agreement with experimental data on calcareous metapelites (Domanik and Holloway, 2000) showing that phengite, the main carrier of $\mathrm{N}$, is stable up to $9 \mathrm{GPa}$ for a geothermal gradient of about $8^{\circ} \mathrm{C} / \mathrm{km}$. The interpretation that nitrogen can be deeply recycled to the mantle is also supported by the occurrence of high concentrations of nitrogen (up to $11000 \mathrm{ppm}$ ) in UHP metamorphic diamonds (P > 40 kbar; Cartigny et al., 2001), yet contrast with the interpretation that $\mathrm{N}$ can be efficiently recycled in arc lavas associated with hot slab environment (Fisher et al., 2002). Many studies have highlighted the central role of serpentinites as sources of volatiles in subduction zones (Scambelluri and Philippot, 2001; Scambelluri et al., 2004; Sharp and Barnes, 2004; Straub 
and Layne, 2003), yet to date no study has identified serpentinites as a source of $\mathrm{N}$ in the genesis of island arc magmas. In the present paper, we investigate the nitrogen contents and $\mathrm{N}$ isotopic composition of a suite of ultramafic rocks from the Alpine Erro Tobbio complex, which has experienced oceanic hydrothermal alteration and subduction zone metamorphism up to ultra-high pressure conditions $\left(2.5 \mathrm{GPa}\right.$ and $650^{\circ} \mathrm{C}$; the data presented in this study are from the $\mathrm{PhD}$ thesis of Busigny, 2004). In order to provide a reference frame to the results obtained on these metamorphic rocks, serpentinite from the South West Indian Ridge were also analyzed. The results are compared with previous oxygen isotope systematics on the same set of samples (Früh-Green et al., 2001) and with $\mathrm{N}$ isotope systematics on associated mafic rocks and metasediments from the Schistes Lustrés nappe (Busigny et al., 2003a). The data presented represent the first inventory of $\mathrm{N}$ behaviour in a typical oceanic lithosphere subducted along a 'cold' geothermal gradient $\left(8^{\circ} \mathrm{C} / \mathrm{km}\right)$, representative of most current subduction zones.

\section{Samples and analytical technique}

The volatile and mobile elements in the oceanic mantle and in metasediments were analyzed in sample suites from the Alpine-Apennine system. The Alpine-Apennine ophiolites are important natural observatories for the progressive subduction of variably altered oceanic lithosphere and can be used as monitors of deep fluid and element loss into the Earth's mantle (Philippot and Selverstone, 1991; Philippot, 1993; Barnicoat and Cartwright, 1997; Scambelluri et al., 1997; FrühGreen et al., 2001; Scambelluri and Philippot, 2001). The selected utramafic rocks record key evolutionary stages of (1) hydration of the oceanic mantle, (2) fluid release at partial dehydration of serpentine (olivine-in reaction) and formation of high-pressure metamorphic veins. Detailed sample descriptions and the relative bibliographic information are reported in Scambelluri et al. (2004) and in Busigny (2004) and are only summarized below. 


\section{Ultramafics}

The sample set selected is from the Erro Tobbio Complex of the Ligurian Alps. The rocks studied show a variety of equilibration from shallow alteration in an oceanic environment up to eclogite facies conditions (Scambelluri et al., 1995). Early stage of serpentinization occurred at $\mathrm{T}<300{ }^{\circ} \mathrm{C}$ and $\mathrm{P}<0.25 \mathrm{GPa}$, as indicated by stable chrysotile. High pressure antigorite serpentinites formed at increasing PT conditions up to $2.5 \mathrm{GPa}$ and $650^{\circ} \mathrm{C}$, which was contemporaneous with eclogitization of associated mafic rocks (Messiga et al., 1995). The antigorite serpentinites display overgrowth of pre-subduction chrysotile assemblages by eclogite-facies olivine + antigorite + Ti-clinohumite + chlorite + diopside, formed after partial dehydration of the precursor serpentinite (olivine-in reaction). Presence of a fluid phase is documented by olivine-veins (olivine + Ti-clinohumite + chlorite + diopside \pm antigorite; Scambelluri et al., 1997). To study the $N$ content and isotopic systematics during oceanic serpentinization and HP metamorphism and veining, the analytical work was performed on a cross section including low-strain peridotites displaying variable oceanic serpentinization and high-pressure serpentinite mylonites and veins. Samples analyzed here are from the study of Scambelluri et al (2001; their figure 1). These comprises three low strain serpentinized peridotites (ETF1, ETF2, ETF3) and three HP mylonitic serpentinites (ETF4, ETF6, ETF7). One HP vein (ET0903-V) composed of olivine, Ti-clinohumite and antigorite and its host rock (ET0903-WR)serpentinite have been also analyzed (Busigny, 2004). In addition to these, three oceanic serpentinites from the South West Indian Ridge (SWIR) have been analyzed to provide an independant estimate of $\mathrm{N}$ budget in modern day environment. These are DR23-2-1, DR23-2-8 and DR23-3-5 (see Decitre et al., 2002 for a detailed petrological and major and trace element analysis). All samples are undeformed spinel lherzolite showing different degree of serpentinization (from 67 to $82 \%$ ) and preserving relics of mantle olivine, orthopyroxyne, clinopyroxene and spinel.

\section{(Meta) sediments}


The pelitic rocks sampled include unmetamorphosed oceanic sediments from the Apennines and their high and ultrahigh pressure counterparts of the western Alps. The (meta)sediments studied are from the Lavagna Unit in the Internal Liguride zone (northern Apennine) and the Schistes Lustrés nappe from the Penninic zone (western Alps; Busigny et al., 2003a). These rocks represent pelagic sediments equilibrated under increasing PT conditions along a cold subduction path. The sediments from Lavagna Unit consists of unmetamorphosed middle Jurassic to late Cretaceous radiolarian chert, Calpionella-limestone and Palombini-shale which experienced diagenesis at $\mathrm{P}<0.17 \mathrm{GPa}$ and $\mathrm{T}<300{ }^{\circ} \mathrm{C}$ (Reinhardt, 1991). Samples contain variable proportions of calcite, clay minerals and quartz. Calc-schists from the Schistes Lustrés nappe consist of quartz, phengite, paragonite and carbonate, subordinate chlorite, rutile and graphite. The rock suite equilibrated at increasing PT conditions as attested by the presence of lawsonite and carpholite (Lago Nero and Fraiteve), chloritoid (Colle di Assietta), garnet (Colle delle Finestre) and coesite (Lago di Cignana). PT estimates include: Lago Nero $\left(\mathrm{T}=300^{\circ} \mathrm{C}\right.$ and $\mathrm{P} \leq 0.8 \mathrm{GPa}$; Martin and Polino, 1984), 2) Fraiteve ( $\mathrm{T}$ $=350^{\circ} \mathrm{C}$ and $\mathrm{P} \leq 1.5 \mathrm{GPa}$; Agard et al., 2001), Colle di Assietta $\left(\mathrm{T}=400^{\circ} \mathrm{C}\right.$ and $\left.\mathrm{P} \leq 1.8 \mathrm{GPa}\right)$, Colle delle Finestre $\left(\mathrm{T}=450^{\circ} \mathrm{C}\right.$ and $\left.\mathrm{P} \leq 2.0 \mathrm{GPa}\right)$ and Lago di Cignana $\left(\mathrm{T}=650^{\circ} \mathrm{C}\right.$ and $\mathrm{P} \leq 3.0 \mathrm{GPa}$; Reinecke, 1991).

\section{Analytical techniques}

Nitrogen content and isotopic composition were measured using sealed tube combustion technique coupled with static mass spectrometry (Boyd et al., 1994; Ader et al., 2006; Busigny et al., 2005). In a companion paper, it was shown that this technique provides accurate and reproducible results for analyses of rocks samples with $\mathrm{N}$ content as low as 2 ppm (Busigny et al., 2005). The whole-rock samples were ground to thin powders and homogenized. Nitrogen was extracted from sample powders during a combustion step in quartz tubes sealed under vacuum. Nitrogen was purified and separated from other volatiles (mainly $\mathrm{H}_{2} \mathrm{O}$ ) using $\mathrm{CaO}, \mathrm{Cu}$ and $\mathrm{CuO}$. 
The sealed tubes were loaded into a vacuum line and opened with a tube cracker. Nitrogen was purified and quantified as dinitrogen $\mathrm{N}_{2}$ by capacitance manometry with a precision better than $8 \%$ $(2 \sigma)$. The amount of extracted $\mathrm{N}$ ranged between 30 and $300 \mathrm{nmol}$ in sedimentary rocks and between 4 to $17 \mathrm{nmol}$ in the ultramafics. The gas was then isotopically analyzed using a triplecollector static mass spectrometer. Variations in the $\mathrm{N}$ isotopic composition of the samples are expressed in the usual $\delta$ notation (in \%o): $\delta^{15} \mathrm{~N}_{\text {sample }}=\left[\left({ }^{15} \mathrm{~N} /{ }^{14} \mathrm{~N}\right)\right.$ sample $\left./\left({ }^{15} \mathrm{~N} /{ }^{14} \mathrm{~N}\right)_{\text {standard }}-1\right] \times 1000$, where the standard is atmospheric $\mathrm{N}_{2}$. Possible carbon monoxide and atmospheric contamination was monitored in the mass spectrometer using $\mathrm{m} / \mathrm{z}=12,30$ and $40(\mathrm{Ar})$. The accuracy of $\delta^{15} \mathrm{~N}$ values was estimated at $\pm 0.5 \%$ o $(2 \sigma)$ from the reproducibility of international standards (IAEA-N1 and -N2). The nitrogen blank amount was $0.65 \pm 0.30 \mathrm{nmol} \mathrm{N}$, with a mean $\delta^{15} \mathrm{~N}$ at $-3.7 \pm 2.7 \%$ ( $2 \sigma$; for details see Busigny et al., 2005).

In order to test any potential effect of the serpentinization process on the $\mathrm{N}$ behavior, it is important to compare $\mathrm{N}$ content and isotopic composition to a sepentinization index like water content. While water contents of SWIR ultramafic rocks have been determined previously (Decitre, 2000), those of Erro-Tobbio rocks have been measured in the present study. Samples powders $(\sim 30$ $\mathrm{mg}$ ) were loaded in quartz tubes connected to a vacuum line. The powders were degassed during $\sim 12 \mathrm{hr}$ at $150^{\circ} \mathrm{C}$ under vacuum. Water was extracted from $\mathrm{OH}$-bearing minerals by fusion of the sample at $1200^{\circ} \mathrm{C}$. Potential traces of hydrogen, as $\mathrm{H}_{2}$, were oxidized to water with $\mathrm{CuO}$ heating at $450^{\circ} \mathrm{C}$. Water was purified from other gases (mainly $\mathrm{CO}_{2}$ and $\mathrm{N}_{2}$ ) on a variable-temperature trap at $145^{\circ} \mathrm{C}$ and then converted to $\mathrm{H}_{2}$ passing through hot uranium $\left(800^{\circ} \mathrm{C}\right.$; Bigeleisen et al., 1952). The hydrogen was quantified manometrically using a Toepler pump and the water content was calculated assuming all the hydrogen was initially present as water in the rock. The analytical error for water content is estimated to be better than $0.1 \%(2 \sigma)$. 


\section{Nitrogen content and isotopic composition in the serpentinized oceanic mantle}

Bulk rock nitrogen analysis of SWIR and Erro Tobbio ultramafic rocks are given in Table 1 and 2. Each sample has been analyzed at least twice in order to check the analytical reproducibility. SWIR samples show $\mathrm{N}$ content between 2.0 and $2.9 \mathrm{ppm}$ and $\delta^{15} \mathrm{~N}$ between +6.3 and $+7.5 \%$. Nitrogen content of Erro Tobbio serpentinized peridotites ranges between 3.9 and $5.9 \mathrm{ppm}$, which is slightly higher than $\mathrm{N}$ content of HP mylonitic serpentinites (1.4 to $2.8 \mathrm{ppm}$ ). With the exception of the HP vein $\left(\delta^{15} \mathrm{~N} \pm 3.7 \%\right.$ ), all Erro Tobbio samples show $\delta^{15} \mathrm{~N}$ values between +8.9 and $+15 \%$.

Figure 1 shows that no correlation seems to exist between $\mathrm{N}$ content and $\delta^{15} \mathrm{~N}$ of all analyzed Erro Tobbio and SWIR samples. Water contents of the analyzed SWIR samples were estimated between 9.6 and $13.7 \mathrm{wt} \%$. Figure 2 shows that the SWIR samples display highly variable water content at relatively constant $\mathrm{N}$ concentration, indicating that $\mathrm{N}$ is unaffected by the degree of serpentinization. Erro Tobbio serpentinized peridotites and HP mylonitic serpentinites show a remarkable negative linear correlation characterized by decreasing $\mathrm{N}$ content at increasing $\mathrm{H}_{2} \mathrm{O}$ concentrations. $\mathrm{N}$ content of the $\mathrm{HP}$ vein is about 5 times higher $(5.3 \mathrm{ppm})$ than the host mylonite (1.4 ppm) with a markedly lower $\mathrm{H}_{2} \mathrm{O}$ content (from 11 to about $5 \mathrm{wt} \% \mathrm{H}_{2} \mathrm{O}$ ). $\delta^{15} \mathrm{~N}$ values of Erro Tobbio and SWIR samples show no correlation with the $\mathrm{H}_{2} \mathrm{O}$ contents (Figure 3). The HP vein is significantly depleted in ${ }^{15} \mathrm{~N}$ compared with its HP host rock.

\section{Nitrogen composition of subducted sediments}

Figure 4 shows the bulk $\mathrm{N}$ contents vs $\delta^{15} \mathrm{~N}$ values of the unmetamorphic and HP metasediments from the Lavagna and Schistes Lustrés nappes (data from Busigny et al., 2003a). In these rocks, nitrogen occurs mainly as ammonium $\left(\mathrm{NH}_{4}{ }^{+}\right)$and is substituted for potassium in $\mathrm{K}$-bearing minerals Analysis of individual phengite using FTIR spectrosocopy showed that ammonium is mainly in phengite and that its concentration is homogeneous on a sample scale but vary significantly between 
samples. Whole rock $\mathrm{N}$ contents vary range from about 100 to $1700 \mathrm{ppm}$ (Busigny et al., 2003b). This large variation recorded between samples is sedimentary in origin and reflects the proportion of K-bearing mineral in the protolith. Whole-rock $\delta^{15} \mathrm{~N}$ values range between +2.6 and $+4.8 \%$. As shown in Figure 4, the different rock types show the same range in $\delta^{15} \mathrm{~N}$ values independent of their metamorphic grade and bulk nitrogen concentrations. Together with other geochemical evidence, like the constant ratios of $\mathrm{K}, \mathrm{Rb}, \mathrm{Cs}$ and $\delta \mathrm{D}$ (Busigny et al. 2003a), these data indicate that $\delta^{15} \mathrm{~N}$ values were unaffected by metamorphism and $\mathrm{N}$ was not released during subduction down to $90 \mathrm{~km}$ depth.

\section{Discussion and conclusions}

Figures 2 and 3 show that SWIR serpentinized peridotites display a slight increase in bulk $\mathrm{N}$ concentrations and relatively constant $\delta^{15} \mathrm{~N}$ values despite a large variability in $\mathrm{H}_{2} \mathrm{O}$ content. Considering that the increase in $\mathrm{N}$ content in the most hydrated samples is real, this suggests that the $\mathrm{N}$ budget could be controlled by the serpentinization process. In contrast, the Erro Tobbio serpentinized peridotites and HP mylonitic serpentinites display a marked negative linear correlation between $\mathrm{N}$ and $\mathrm{H}_{2} \mathrm{O}$ contents at similar $\delta^{15} \mathrm{~N}$ Values. Dehydration processes attending subduction are unlikely to explain this correlation as the HP mylonites show a significant enrichment in water compared to the low strain peridotites. We rather favor the idea that $\mathrm{N}$ loss from low strain serpentinized peridotites to HP mylonitic serpentinites can be due to deformation. Recognition that the HP vein contains the same N amount than the low-strain peridotite suggests that $\mathrm{N}$ loss attending mylonitization of the low-strain serpentinized peridotites into the HP mylonites could be balanced by N trapping in the HP veins. Alternatively, Früh-Green et al. (2001) suggested that two fluid sources could be involved in the hydration processes of the Erro Tobbio peridotites. A typical oceanic fluid origin attending mid-oceanic ridge hydrothermal circulation and a dehydration/compaction-derived fluid released in the sedimentary accretionary wedge and driving 
secondary serpentinization in the forearc region. In this model, the first fluid source would be responsible for the increase of the $\mathrm{N}$ content of the serpentinites with the degree of hydration of the samples (SWIR samples). The origin and location of $\mathrm{N}$ in the serpentinites is unknown but could resides in the sealed voids and cracks produced by the serpentinization process as it as been proposed for $\mathrm{NaCl}$ derived from seawater (Sharp \& Barnes 2004). The second fluid source originating in the accretionary wedge would have introduced metamorphic water into the deforming low-strain peridotite, which is now being further serpentinized. This fluid would be poor in $\mathrm{N}$ to the degree it is not derived from dehydrating metasedimentary phengite, which is the main $\mathrm{N}$ carrier (see below). By partly percolating the pre-existing hydrothermally-derived serpentinite, part of the $\mathrm{N}$ would be progressively leached out of the deforming HP mylonites and expelled into the local HP veins.

Constraints on the potential role of externally-derived fluid sources during Erro Tobbio dewatering processes attending vein formation can be achieved using isotope systematics and trace element characterisitics of Erro Tobbio rocks and surrounding mafic and metasedimentary rock protoliths. In order to evaluate the possible source of nitrogen involved in vein formation during HP metamorphism, the isotopic composition of the studied SWIR and Erro Tobbio serpentinites are plotted together with that of metasedimentary rocks (Busigny et al., 2003a) and ophiolitic metagabbros (Busigny 2004; unpublished data) from the same Schistes Lustrés nappe. Figure 5 shows that a fluid-derived contamination arising from either metasediments or metagabbros could account for the observed $\delta^{15} \mathrm{~N}$ value of the HP vein. Figure 6 plots the oxygen isotopic composition of the Erro Tobbio oceanic serpentinites, HP serpentines and veins together with associated eclogitic metagabbros of Früh-Green et al, (2001) as well as the range of $\delta^{18} \mathrm{O}$ values of Alpine metasedimentary rocks of Henry et al (1996). The range of $\delta^{18} \mathrm{O}$ of the HP serpentinite veins is similar to that of surrounding metagabbros but very different from the HP metasediments by more than 10 to $20 \%$. In contrast to $\mathrm{N}$, which is a trace element, hence sensitive to fluid processes, oxygen is a major supporting element of silicate minerals. Modifying the $\delta^{18} \mathrm{O}$ signature of a rock 
would require much greater quantities of exchanging material. Yet, if a fluid phase derived from the sediments was percolating the ultramafic/gabbroic sequence, one would expect to see an effect on the HP serpentinite vein isotopic composition. Considering that the sediments $\delta^{18} \mathrm{O}$ values range between 15 and 20\%o, and that the host serpentinite $\delta^{18} \mathrm{O}$ values range between 5 and $8 \%$, a fluid of sedimentary origin controlling HP serpentinite vein formation should produce a higher ${ }^{18} \mathrm{O}$ imprint than the surrounding HP mylonites. The HP vein shows a significantly lower $\delta^{18} \mathrm{O}$ values than its host mylonitic serpentinite, which is at odd with a sedimentary fluid component involved in their source. The fact that the HP veins show the same range of $\delta^{18} \mathrm{O}$ values as the surrounding metagabbros suggests a local buffering by the metagabbros. Further supports for a local origin of the fluids arises from the large range of $\delta^{18} \mathrm{O}$ of the serpentinite veins, hence large heterogeneity of the veins, which is best accounted for by a relatively small-scale of isotopic equilibration. Involvement of a gabbroic component in the formation of the HP veins is also supported, although not demonstrated, by the trace element composition of the veins. As shown in Figure 7 , the normalized trace element pattern of the Erro Tobbio HP veins display a positive Ti anomaly which is not present in the host HP serpentinites (Scambelluri et al., 2001). This is best explained by the involvement of surrounding Fe-Ti metagabbros (Scambelluri et al., 1995) rather than a metasedimentary source. We conclude that the HP vein is probably not representative of the fluids released during mylonitization. In our view, the most likely explanation is that deformation is the key parameter to account for the negative correlation between $\mathrm{H}_{2} \mathrm{O}$ and $\mathrm{N}$-contents found in Figure 2. Increasing water content may have enhanced deformation, which in terms may have favored $\mathrm{N}$ released from the rock "porosity" or mineral structure depending of where $\mathrm{N}$ is localized in serpentinites. This model relies heavily on the assumption that available data on present-day altered peridotites from the SWIR could be extended to Alpine samples. Additional studies are required to test this assumption. 
The Erro Tobbio ultramafics studied here and associated metasediments from the Schistes Lustrés nappe investigated by Busigny et al., (2003a) can be considered as representative of processes active down to the depth locus of island arc magmatism (i.e. 90-100 km depth) in most modern subduction zones. Our $\mathrm{N}$ isotope analysis of serpentinites coupled with $\delta^{18} \mathrm{O}$ systematics envisages the involvement of a mafic (crustal) component during partial deserpentinization of the subducted oceanic mantle at the depth locus of island arc magmatism. This does not necessarily imply large scale fluxes as the metagabbros are spatially associated with the analyzed serpentinites, rather preservation of presubduction chemical and isotopic heterogeneities on a local scale as documented in Alpine metasediments (Busigny et al., 2003a) and in mafic protoliths (e.g., Philippot, 1993; Barnicoat and Cartwright, 1997; Scambelluri and Philippot, 2001). The HP vein contains metamorphic olivine that formed at the expense of antigorite at minimum pressure of about 2.5 $\mathrm{GPa}$. This indicates that $\mathrm{N}$ could be recycled continuously into newly formed HP minerals during subduction to great depth, hence supporting the notion that $\mathrm{N}$ stored in ultramafic rocks could be subducted far deeper than the depth locus of island arc magmatism.

The role of serpentinites in recycling nitrogen and other volatiles in subduction zones remains largely unknown due to large uncertainties in estimating the degree of serpentinization of the oceanic lithosphere (Mével, 2003). In fast spreading ridges, most evidence suggests that the crust is layered and consists of extrusive basalts, a dike complex and a massive gabbro layer overlying mantle peridotites, with little evidence of serpentinized peridotites. In contrast, Cannat et al., (1987) suggested for low spreading rates that exposure of serpentinites could represent $20 \%$ of the seafloor, that is about $5-15 \%$ in volume of the crust. In modern environment, considering the vast extension of fast spreading ridge compare to slow and ultraslow spreading ridges suggests that the degree of serpentinization should not exceed a few $\%$ of the lithosphere (Mével, pers. comm.). Estimated fluxes of basalts and gabbros are of the order of $2.010^{16}$ and $4.010^{16} \mathrm{~g} / \mathrm{yr}$, respectively (Peacock, 1990). Considering that serpentinized peridotites represent $5 \%$ at most of the oceanic lithosphere leads to a flux of serpentinites of about $3.010^{15} \mathrm{~g} / \mathrm{yr}$. Considering a mean $\mathrm{N}$ concentration of 3.2 
ppm for serpentinites results a $\mathrm{N}$ flux estimates of about $910^{9} \mathrm{~g} / \mathrm{yr}$. This value is 2 order of magnitude lower than the sedimentary $\mathrm{N}$ flux $\left(7.210^{11} \mathrm{~g} / \mathrm{yr}\right.$, Busigny et al., 2003a), thus suggesting that the contribution of serpentinized peridotites to the $\mathrm{N}$ budget is minor compared to that of sediments and mafic rocks. Clearly, additional constraints on the degree of serpentinization of the oceanic lithosphere are needed to test this hypothesis.

\section{Acknowledgements.}

We thank Alexander Proyer and the organizers of the $7^{\text {th }}$ International Eclogite Conference for the invitation to participate to the meeting and to present a paper in this volume. This paper benefited from the comments of two anonymous reviewers. This work was supported by INSU-CNRS. This is IPGP contribution $n^{\circ} 2134$. 


\section{References}

Ader M, Cartigny P, Boudou JP, Oh JH, Petit E, Javoy M (2006) Nitrogen isotopic evolution of carbonaceous matter during metamorphism: Methodology and preliminary results. Chem. Geol. in press.

Agard P, Jolivet L, Goffé B (2001) Tectonometamorphic evolution of the Schistes Lustrés Complex: implications for the exhumation of HP and UHP rocks in the western Alps. Bull. Soc. Geol. Fr. 5: 617-636.

Barnicoat A C, Cartwright I (1995) Focused fluid flow during subduction: Oxygen isotope data from high-pressure ophiolites of the western Alps. Earth Planet. Sci. Lett. 132: 53-61.

Bebout GE, Fogel M (1992)Nitrogen-isotope compositions of metasedimentary rocks in the Catalina Schist, California: implications for metamorphic devolatilization history. Geochim. Cosmochim. Acta 56: 2839-2849.

Bigeleisen, J., M.L. Perlman and H.C. Prosser (1952) Conversion of hydrogenic materials to hydrogen for isotopic analysis. Anal. Chem. 24: 1356-1357.

Boyd SR, Rejou-Michel A, Javoy M (1994) Noncryogenic purification of nanomole quantities of nitrogen gas for isotopic analysis. Anal. Chem. 66: 1396-1402.

Busigny V, Cartigny P, Philippot P, Ader M, Javoy M (2003a) Massive recycling of nitrogen and other fluid-mobile elements $(\mathrm{K}, \mathrm{Rb}, \mathrm{Cs}, \mathrm{H})$ in a cold slab environment: evidence from HP to UHP oceanic metasediments of the schistes Lustrés nappe (western Alps, Europe). Earth. Planet. Sci. Lett. 215: 27-42.

Busigny V, Cartigny P, Philippot P, Javoy $M$ (2003b) Amonium quantification in muscovite by infrared spectroscopy. Chem. Geol. 198: 21-31.

Busigny V (2004) Comportement géochimique de l'azote dans les zones de subduction. PhD Thesis, Université Denis Diderot, 301pp.

Busigny V, Ader M, Cartigny P (2005) Quantification and isotopic analysis of nitrogen in rocks at the ppm level using sealed-tube combustion technique: A prelude to the study of altered oceanic crust, Chem. Geol. 223: 249-258.

Cannat M, Mével C, Maïa M, Deplus C, Gente P, Agrinier P, Belarouchi A, Dubuisson G, Humler E, Reynolds JR (1995) Thin crust, ultramafic exposure and rugged faulting patterns at the Mid-Atlantic Ridge $\left(22^{\circ}-24^{\circ} \mathrm{N}\right)$. Geology 23: 49-52.

Cartigny P, De Corte K, Shatsky VS, Ader M, De Paepe P, Sobole NV, Javoy M (2001) The origin and the formation of metamorphic microdiamonds from the Kokchetav massif, Kazakhstan: a nitrogen and carbon isotopic study. Chem Geol. 176: 265-281.

Decitre $S$ (2000) Variations de la composition isotopique du lithium dans les péridotites océaniques serpentinisées et dans le manteau: Implications pour le cycle du lithium. $\mathrm{PhD}$ Thesis, Institut National Polytechique de Lorraine, 250pp.

Decitre S, Deloule E, Reisberg L, James R, Agrinier P, Mèvel C (2002) Behavior of Li and its isotopes during serpentinization of oceanic peridotites. Geochem. Geophys. Geosystems. 3: 1007:DOI 10.1029/2001GC000178

Domanik KJ, Holloway JR (2000) Experimental synthesis and phase relations of phengitic muscovite from 6.5 to $11 \mathrm{GPa}$ in a calcareous metapelite from the Dabie Mountains, China. Lithos

52: $51-77$.

Fischer TP, Hilton DR, Zimmer MM, Shaw AM, Sharp ZD,Walker JA (2002) Subduction and recycling of nitrogen along the Central American margin: Science

297:154-1157.

Früh-Green G L, Scambelluri M, Vallis F (2001) O-H iso ope ratios of high-pressure ultramafic rocks: Implications for fluid sources and mobility in the subducted hydrous mantle. Contrib. Mineral. Petrol. 141: 145-159. 
Henry C, Burkhard M, Goffé B (1996) Evolution of synmetamorphic veins and their wallrocks through a Western Alps transect: no evidence for large-scale fluid flow. Stable isotope, major- and trace-element systematics. Chem. Geol. 127: 81-109.

Hermann J, Green DH (2001) Experimental constraints on high pressure melting in subducted crust. Earth. Planet. Sci. Lett., 188: 149-168

Martin S, Polino R (1984) Le metaradiolariti a ferro di Cesana (Valle di Susa-Alpi occidentali). Mem. Soc. Geol. It. 29: 107-125.

Messiga B, Scambelluri M, Piccardo GB (1995) Formation and breakdown of chloritoid-omphacite high-pressure assemblages in mafic systems: evidence from the Erro-Tobbio eclogitic metagabbros (Ligurian Western Alps). Eur. J. Mineral. 7: 1149-1167.

Mével C (2003) Serpentinization of abyssal peridotites at mid-ocean ridges. C. R. Geoscience 335: $825-852$.

Mingram B, Bräuer $K$ (2001) Amonium concentration and Nitrogen isotope composition in metasedimentary rocks from different tectonometamorphic units of the European Variscan Belt. Geochim. Cosmochim. Acta 65: 273-287.

Moran AE, Sisson VB, Leeman WP (1992) Boron depletion during progressive metamorphism: Implications for subduction processes. Earth. Planet. Sci. Lett. 111: 331-349.

Pawley AR, Holloway JR (1993) Water sources for subduction zone volcanism- new experimental constraints. Science 260: 664-667.

Peacock SM (1990) Fluid Processes in subduction zones. Science 248: 329-336.

Philippot $P$ (1993). "Fluid-melt-rock interaction in mafic eclogites and coesite-bearing metasediments: Constraints on volatile recycling during subduction. Chem. Geol. 108: 93-112.

Philippot P, Selverstone J (1991) Trace-element rich brines in eclogitic veins; Implications for fluid composition and transport during subduction. Contrib. Mineral. Petrol. 106: 417-430.

Poli S, Schmidt MW (2002) Petrology of subducted slabs. Ann. Rev. Earth Planet. Sci. 30: 207-235.

Reinhardt $M$ (1991) Vitrinite reflectance, illite crystalinity and tectonics: results from the Northern Apennines (Italy). Org. Geochem. 17: 175-184.

Reinecke $T$ (1991) Very-high pressure metamorphism and uplift of coesite-bearing metasediments from the Zermatt-Saas Zone, Western Alps. Eur. J. Mineral. 3: 7-17

Scambelluri M, Philippot P (2001) Deep fluids in subduction zones. Lithos 55: 213-227.

Scambelluri M, Muentener O, Hermann J, Piccardo GB, Trommsdorff V (1995) Subduction of water into the mantle: History of an alpine peridotite. Geology 23: 459-462

Scambelluri M, Piccardo GB, Philippot P, Robbiano A, Negretti L (1997) High salinity fluid inclusions formed from recycled seawater in deeply subducted alpine serpentinite. Earth Planet. Sci. Lett. 148: 485-500.

Scambelluri M, Müntener O, Ottolini L, Pettke T, Vannucci $R$ (2004) The fate of $\mathrm{B}, \mathrm{Cl}$ and Li in the subducted oceanic mantle and in the antigorite-breakdown fluids. Earth Planet. Sci. Lett., 222: $217-$ 234.

Scambelluri M, Rampone E, Piccardo GB (2001) Fluid and element cycling in subducted serpentinite: A trace element study of the Erro-Tobbio high-pressure ultramafites (Western Alps, NW Italy). J. Petrol. 42: 55-67.

Shaw AM, Hilton DR, Fischer TP, Walker JA, Alvarado GE (2003) Contrasting He-C relationships in Nicaragua and Costa Rica: insights into $\mathrm{C}$ cycling through subduction zones: Earth Planet. Sci. Lett. 214: 499-513.

Sharp ZD, Barnes JD (2004) Water soluble chlorides in massive seafloor serpentinites: a source of chloride in subduction zones: Earth Planet. Sci. Lett. 226: 243-254.

Straub SM, Layne GD (2003) The systematics of chlorine, fluorine, and water in Izu arc front volcanic rocks: implications for volatile recycling in subduction zones: Geochim. Cosmochim. Acta 67: 4179-4203. 
Synder G, Poreda R, Hunt A, Fehn U (2001) Regional variations in volatile composition: isotopic evidence for carbonate recycling in the Central American volcanic arc: Geochemistry Geophysics Geosystems 2: doi:10.129/2001GC000163.

Ulmer P, Trommsdorff $V$ (1995) Serpentinite stability to mantle depths and subduction-related magmatism. Science 268: 858-861.

Zimmer MM Fischer TP, Hilton DR, Alvarado GE, Sharp ZD, Walker JA (2004) Nitrogen systematics and gas fluxes of subduction zones: insights from Costa Rica arc volatiles: Geochemistry Geophysics Geosystems 5: doi:10.1029/2003GC000651. 
Table 1. Results of $\mathrm{N}$ and $\mathrm{H}_{2} \mathrm{O}$ analyses for serpentinized peridotites from South West Indian Ridge (SWIR).

\begin{tabular}{|c|c|c|c|c|c|}
\hline Sample & $\begin{array}{l}\text { Weight } \\
\text { (mg) }\end{array}$ & $\begin{array}{l}\mathrm{N} \\
(\mathrm{nmol})\end{array}$ & $\begin{array}{l}\mathrm{N} \\
(\mathrm{ppm})\end{array}$ & $\begin{array}{l}\delta^{15} \mathrm{~N} \\
(\% 0)\end{array}$ & $\mathrm{H}_{2} \mathrm{O}(\mathrm{wt} \%)$ \\
\hline \multirow[t]{3}{*}{ DR23-2-1 } & 30.27 & 8 & 3.0 & $6.2_{-0.8}^{+0.6}$ & \\
\hline & \multirow[t]{2}{*}{50.43} & \multirow[t]{2}{*}{11} & 2.8 & $6.4_{-0.7}^{+0.7}$ & \\
\hline & & & 2.9 & 6.3 & $12.9^{\circ}$ \\
\hline \multirow[t]{3}{*}{ DR23-2-8 } & 49.28 & 10 & 2.8 & $7.5_{-0.7}^{+0.7}$ & \\
\hline & \multirow[t]{2}{*}{40.35} & \multirow[t]{2}{*}{9} & 3.0 & $7.4_{-0.7}^{+0.8}$ & \\
\hline & & & 2.9 & 7.5 & $13.7^{*}$ \\
\hline \multirow[t]{3}{*}{ DR23-3-5 } & 50.57 & 8 & 2.0 & $6.9_{-0.8}^{+0.8}$ & \\
\hline & \multirow[t]{2}{*}{35.19} & \multirow[t]{2}{*}{6} & 2.0 & $6.8_{-1.0}^{+0.9}$ & \\
\hline & & & 2.0 & 6.9 & $9.6^{\circ}$ \\
\hline
\end{tabular}

Weight corresponds to sample weight used for $\mathrm{N}$ isotopic analysis. $\mathrm{N}$ (nmol) represent the amount of $\mathrm{N}$ detected by manometry, and $\mathrm{N}(\mathrm{ppm})$ and $\delta^{15} \mathrm{~N}$ the $\mathrm{N}$ content and isotopic composition of samples after blank correction.

"Water content from Decitre (2000). 
Table 2 . Results of $\mathrm{N}$ and $\mathrm{H}_{2} \mathrm{O}$ analyses for Erro Tobbio metaperidotites.

\begin{tabular}{|c|c|c|c|c|c|}
\hline Sample & $\begin{array}{l}\text { Weight } \\
\text { (mg) }\end{array}$ & $\begin{array}{l}\mathrm{N} \\
(\mathrm{nmol})\end{array}$ & $\begin{array}{l}\mathrm{N} \\
(\mathrm{ppm})\end{array}$ & $\begin{array}{l}\delta^{15} \mathrm{~N} \\
(\%)\end{array}$ & $\begin{array}{l}\mathrm{H}_{2} \mathrm{O} \\
(\mathrm{wt} \%)\end{array}$ \\
\hline
\end{tabular}

Low-strain serpentinite peridotites

\begin{tabular}{|c|c|c|c|c|c|}
\hline \multirow[t]{5}{*}{ ETF1 } & 34.36 & 15 & 5.9 & $8.5_{-0.6}^{+0.7}$ & \\
\hline & 28.08 & 12 & 5.7 & n.d. & \\
\hline & 30.32 & 13 & 5.7 & $9.2_{-0.7}^{+0.6}$ & \\
\hline & 39.14 & 17 & 5.8 & $9.1_{-0.6}^{+0.6}$ & \\
\hline & & & 5.8 & 8.9 & 8.42 \\
\hline \multirow[t]{3}{*}{ ETF2 } & 27.48 & 9 & 4.1 & $15.1_{-0.8}^{+0.7}$ & \\
\hline & 29.57 & 9 & 3.8 & $15.0_{-0.8}^{+0.7}$ & \\
\hline & & & 4.0 & 15.0 & 9.30 \\
\hline \multirow[t]{4}{*}{ ETF3 } & 36.26 & 11 & 4.2 & $11.1_{-0.7}^{+0.7}$ & \\
\hline & 28.50 & 9 & 3.9 & $10.9_{-0.8}^{+0.7}$ & \\
\hline & 29.09 & 8 & 3.7 & $10.9_{-0.8}^{+0.8}$ & \\
\hline & & & 3.9 & 11.0 & 9.22 \\
\hline \multicolumn{6}{|c|}{ HP mylonitic serpentinites } \\
\hline \multirow[t]{4}{*}{ ETF4 } & 31.79 & 6 & 2.6 & $11.3_{-0.9}^{+0.8}$ & \\
\hline & 25.63 & 5 & 2.5 & $11.5_{-1.0}^{+1.0}$ & \\
\hline & 25.22 & 5 & 2.6 & $11.1_{-1.0}^{+0.9}$ & \\
\hline & & & 2.6 & 11.3 & 10.23 \\
\hline \multirow[t]{3}{*}{ ETF6 } & 32.09 & 7 & 2.8 & $10.6_{-0.8}^{+0.8}$ & \\
\hline & 27.42 & 6 & 2.8 & $10.5_{-0.9}^{+0.9}$ & \\
\hline & & & 2.8 & 10.6 & 10.73 \\
\hline \multirow[t]{5}{*}{ ETF7 } & 27.86 & 5 & 2.1 & $9.2_{-1.1}^{+1.1}$ & \\
\hline & 35.44 & 5 & 1.9 & $10.3_{-1.0}^{+0.9}$ & \\
\hline & 42.03 & 6 & 1.9 & $8.9_{-0.9}^{+0.8}$ & \\
\hline & 28.95 & 5 & 2.1 & $9.3_{-1.1}^{+1.0}$ & \\
\hline & & & 2.0 & 9.5 & 10.63 \\
\hline \multirow[t]{3}{*}{ ET0903WR } & 42.55 & 5 & 1.3 & $8.8_{-1.0}^{+1.0}$ & \\
\hline & 33.57 & 4 & 1.4 & $9.0_{-1.2}^{+1.1}$ & \\
\hline & & & 1.4 & 8.9 & 10.92 \\
\hline
\end{tabular}

\section{HP vein}

ET0903V

$\begin{array}{ll}37.36 & 14 \\ 35.44 & 15\end{array}$

$\begin{array}{ll}5.1 & 3.5_{-0.7}^{+0.6} \\ 5.4 & 3.9_{-1.0}^{+0.9}\end{array}$

5.3

3.7

4.79

Weight corresponds to sample weight used for $\mathrm{N}$ isotopic analysis. $\mathrm{N}$ (nmol) represent the amount of $\mathrm{N}$ detected by manometry, and $\mathrm{N}(\mathrm{ppm})$ and $\delta^{15} \mathrm{~N}$ the $\mathrm{N}$ content and isotopic composition of samples after blank correction. 


\section{Figure captions}

Fig. 1. Whole rock $\delta^{15} \mathrm{~N}$ values versus $\mathrm{N}$ content for the Erro Tobbio serpentinized metaperidotites and HP vein and mylonitic serpentinites, and the South West Indian Ridge (SWIR) serpentinized peridotites.

Fig. 2. Whole rock $\mathrm{N}$ versus $\mathrm{H} 2 \mathrm{O}$ content for the Erro Tobbio serpentinized metaperidotites and HP vein and mylonitic serpentinites, and the South West Indian Ridge (SWIR) serpentinized peridotites. Shaded area underlines the range of N content of SWIR samples (see text).

Fig. 3. Whole rock $\delta^{15} \mathrm{~N}$ values versus $\mathrm{H} 2 \mathrm{O}$ content for the Erro Tobbio serpentinized metaperidotites and HP vein and mylonitic serpentinites, and the South West Indian Ridge (SWIR) serpentinized peridotites. Shaded area underlines the range of N content of SWIR samples (see text).

Fig. 4. Whole rock $\delta^{15} \mathrm{~N}$ values versus $\mathrm{N}$ content for the HP and UHP metasediments from the Schistes Lustrés nappe and their unmetamorphosed equivalent from the Appennine (data from Busigny et al., 2003a)

Fig. 5. Whole rock $\delta^{15} \mathrm{~N}$ values of the Erro Tobbio metaperidotites, HP vein and mylonitic serpentinite, South West Indian Ridge (SWIR) serpentinized peridotites, Monviso UHP metagabbros and their hydrothermally-altered equivalents from Chenaillet, and HP to UHP metasediments from the Schistes Lustrés nappe and their unmetamorphosed equivalent from the Appennine.

Fig. 6. Whole rock $\delta^{18} \mathrm{O}$ values of the Erro Tobbio metaperidotites, HP vein and mylonitic serpentinite and surrounding HP metagabbros (data from Früh-Green et al., 2001).

Fig. 7. Extended trace element pattern of Erro Tobbio HP vein and mylonitic serpentinite (data from Scambelluri et al., 2001). 


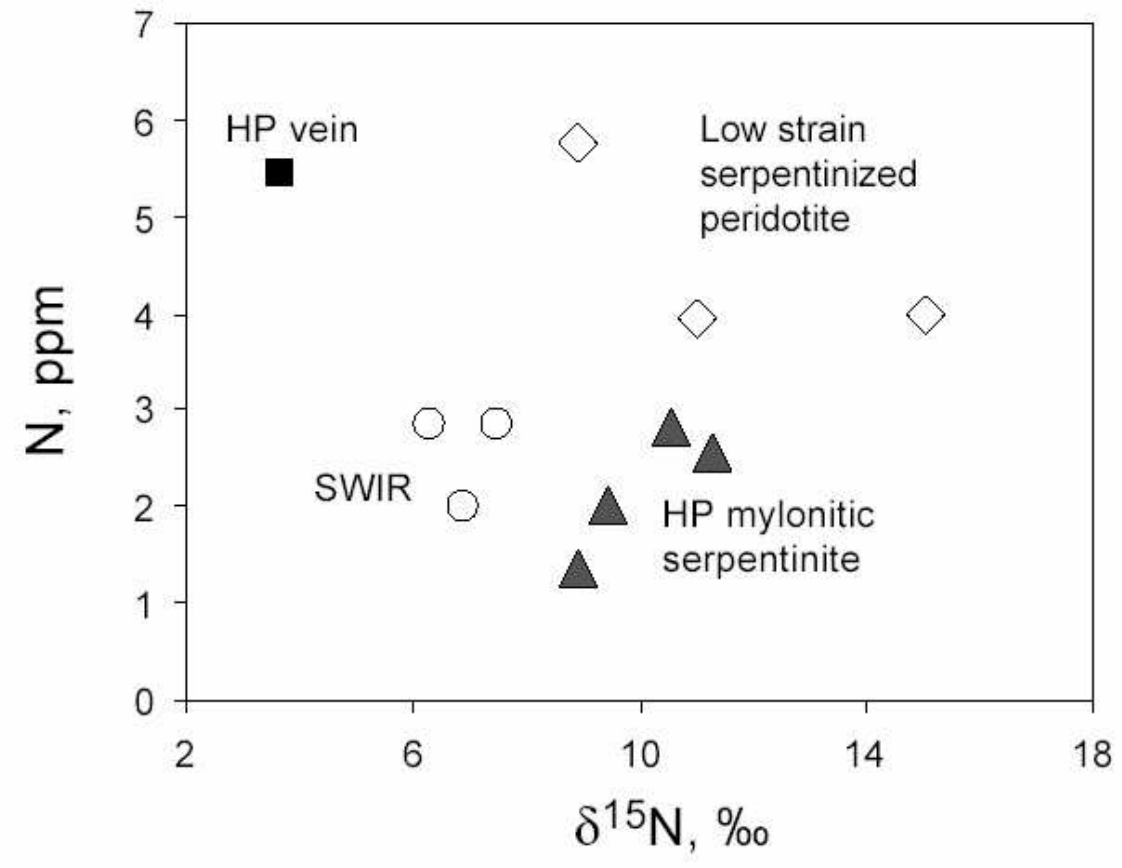

Figure 1 


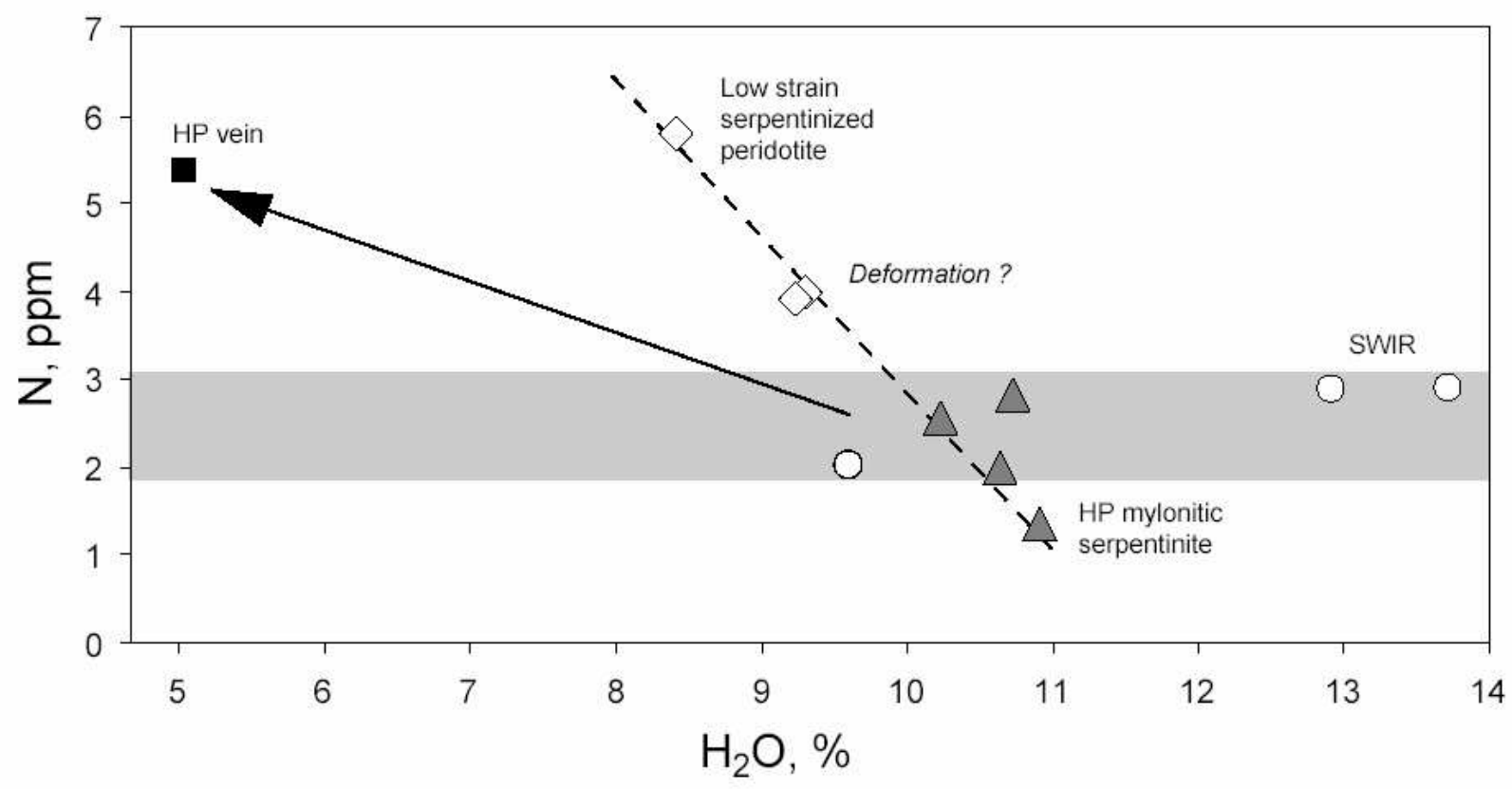

Figure 2 


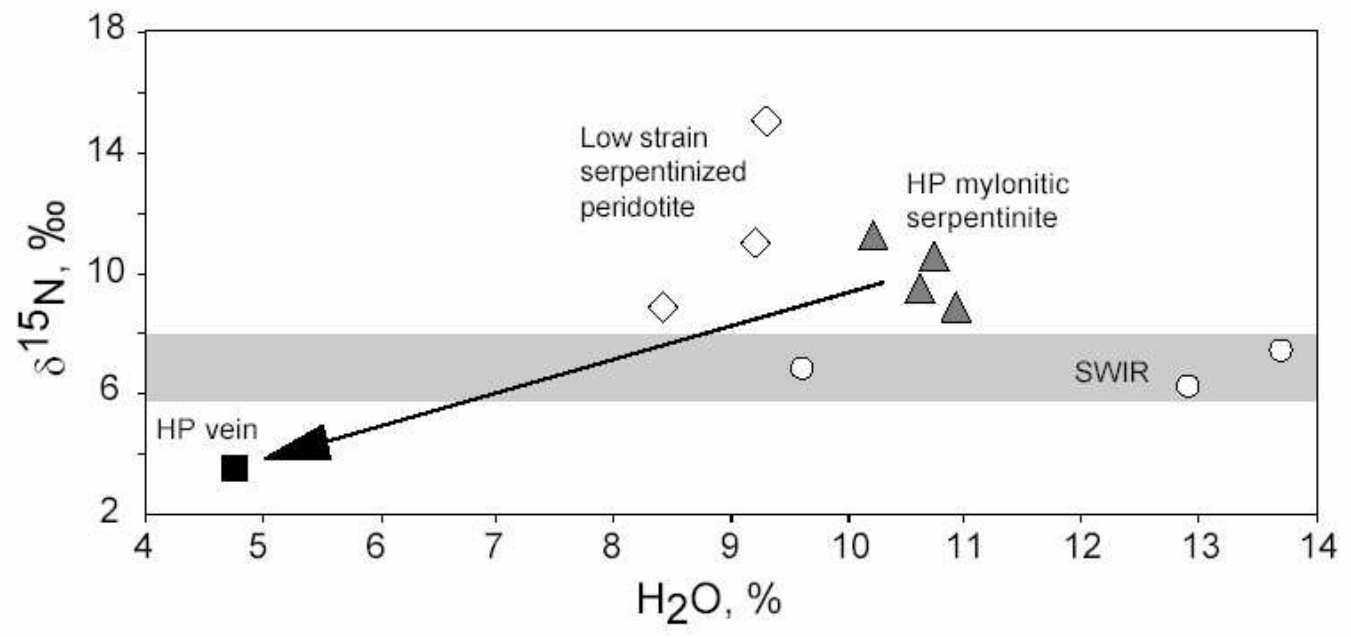

Figure 3 


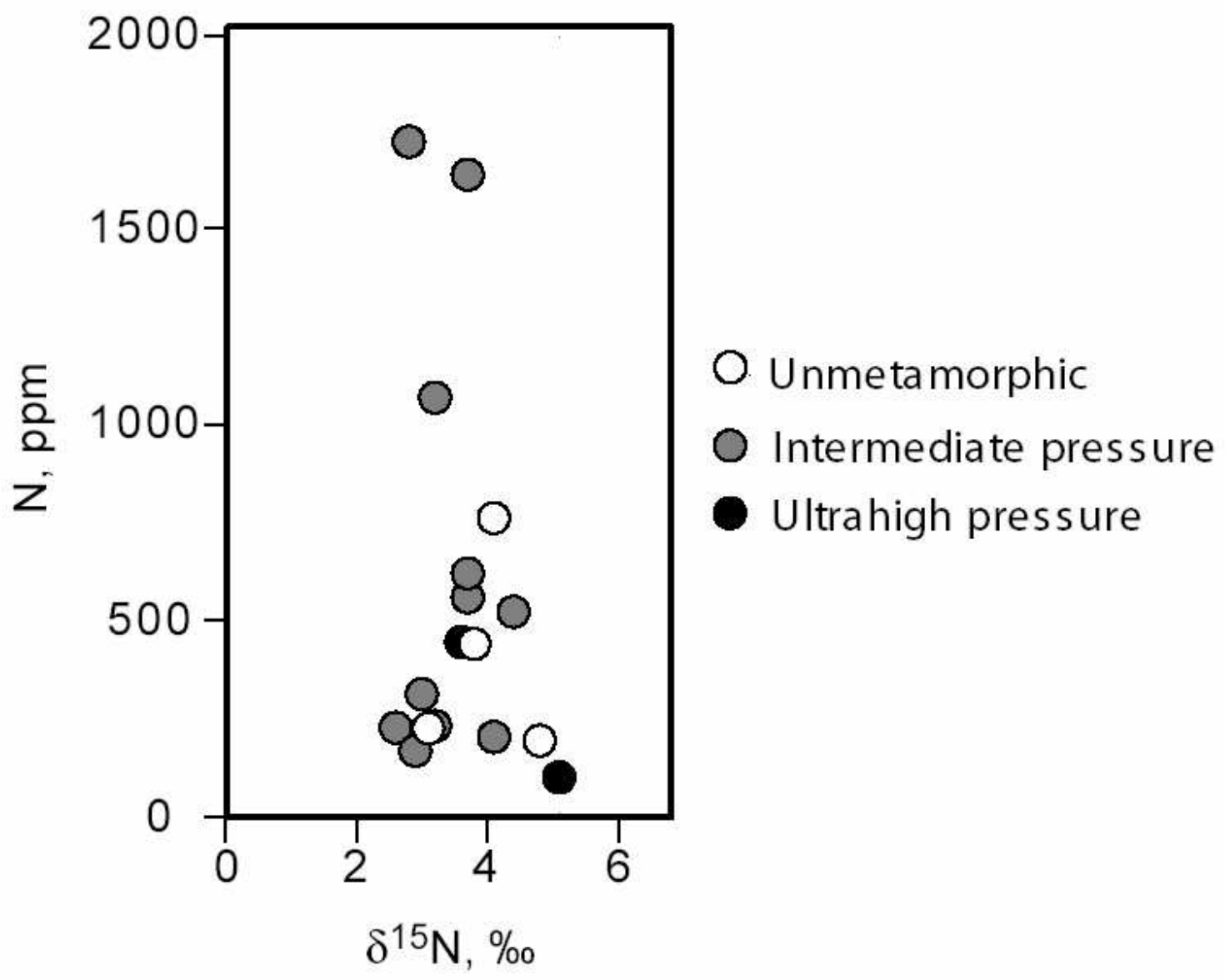

Figure 4 


\section{Sediments $\square$ HP metasediments (Schistes Lustrés)}

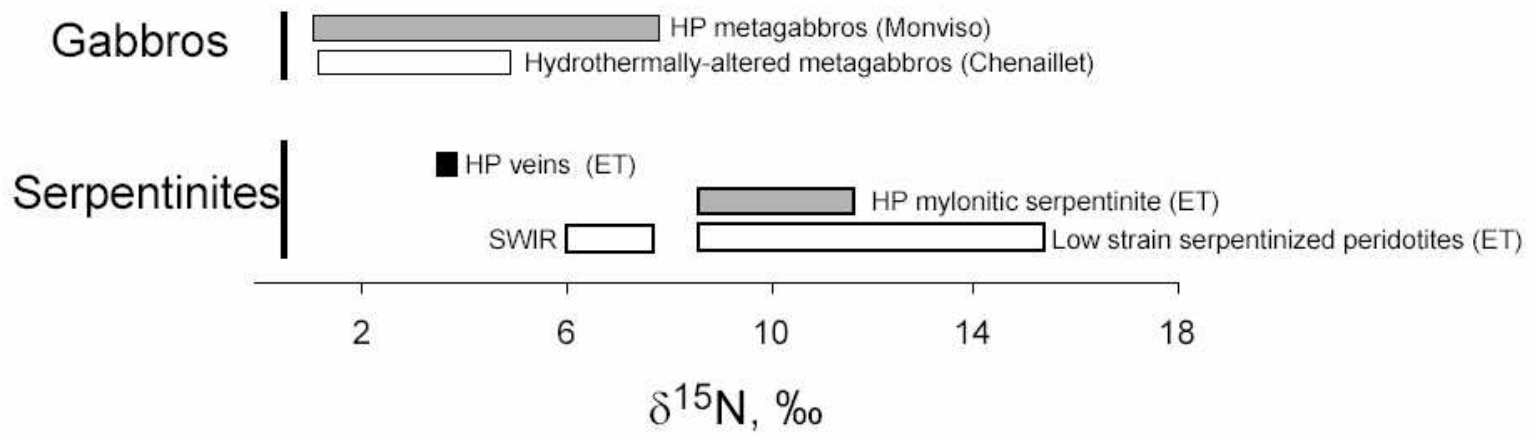

Figure 5 


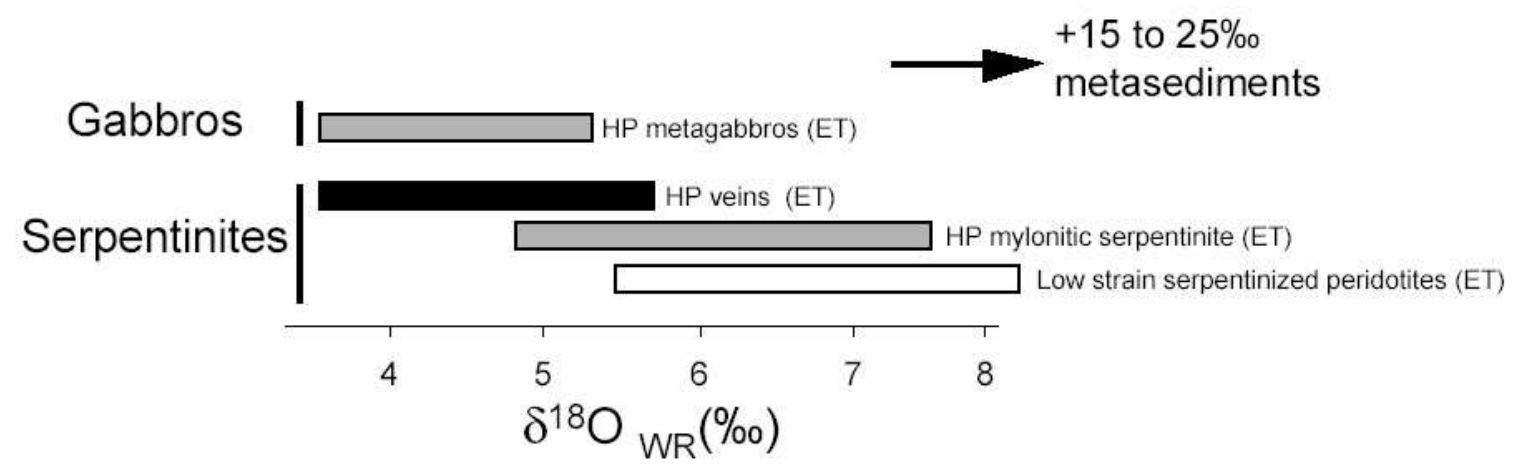

Figure 6 


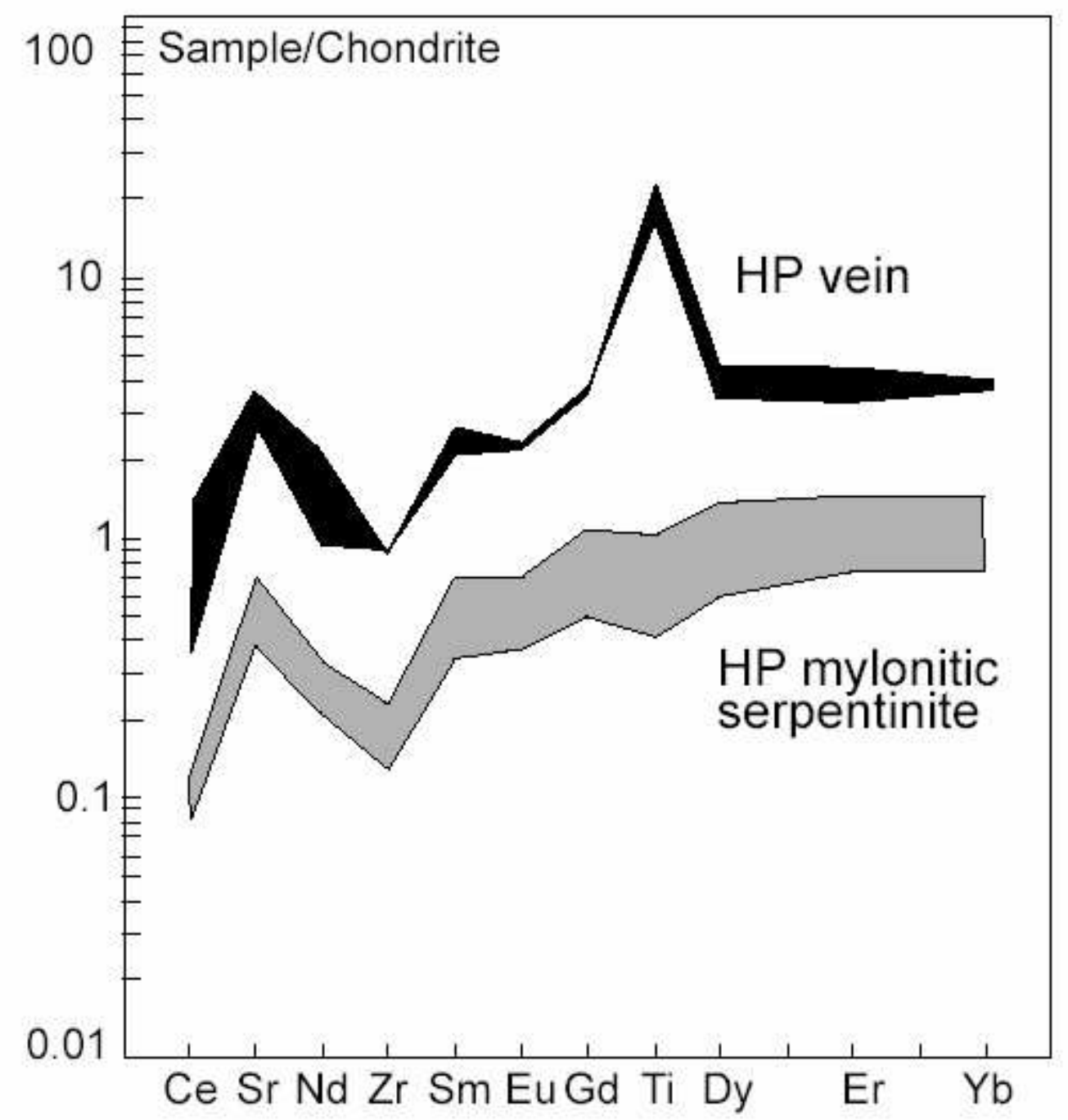

Figure 7 